\title{
Ready to disport with you: Homosocial culture amongst the wool merchants of fifteenth-century Calais ${ }^{1}$
}

And it would please you for your disport and pleasure upon Thursday next coming to meet with us of the east side of this town, in a place called The Pane, you shall find a pair of marked targets of length between one and the other thirteen tailor yards marked out with a line. There we underwritten shall meet with as many of your order and shoot with you at the same targets for a dinner or a supper, price $12 \mathrm{~d}$ a man. And we pray you of your goodly answer within twenty-four hours. Written at Calais the seventeenth day of August, anno Jesu 1478.

Ready to disport with you:

Wedded men Rob Adlyn, John Ekyngton, Philip Williamson, Simon Grantham, Thomas Sharpe, William Bondman, John Dyars, Richard Wylowly, Rob Besten, Thomas Layne, John Wright, Rob Knight

Dorse: To our well-beloved good Brother Thomas Wright and all other Bachelors being Freemen of the Staple be this delivered. ${ }^{2}$

In late summer 1478, a dozen married merchants challenged their bachelor brothers to an archery match. The surviving invitation, found amongst the papers of the wool merchant Cely family, provides rare evidence for mercantile socialising outside of formal feasts, and is particularly notable for its use of a sporting event as a corporate activity. As Raewyn Connell argues in her seminal book Masculinities, the 'institutional 
organization of sport embeds definite social relations: competition and hierarchy among men, exclusion or domination of women.... The performance is symbolic and kinetic, social and bodily, at one and the same time'. Synthesising and expanding on the work of other prominent sociologists, she claims that organised sports play a key role in male identity formation - not just in allowing men to demonstrate individual physical prowess, but more significantly in establishing collective masculine experiences that form a keystone of hegemonic male culture. ${ }^{3}$

Although the function of sports in reifying gender norms into lived practices has been studied now for several decades, this research has tended to focus on professional athletes or 'serious' amateurs. Less systematically studied has been the role of casual sports-playing in homosocial enculturation, particularly in a premodern context. Partly this is undoubtedly because without the records created by official teams, leagues and competitions, casual sports - from the friendly kickabout to the pub darts match - easily disappear from view. In terms of my own field of medieval history, while chivalric field sports such as jousting and civic competitions in archery have been analysed for their role in male identity formation, and despite increasing research interest in recreational activities, there is very little published on the role of recreational sports in establishing communal and individual identities. ${ }^{4}$

Of course part of the reason for this is that 'sports' as they are commonly understood today are 'a modern set of practices closely tied to the rapid evolution of capitalism and the growth of cities. ${ }^{5}$ Sports history, too, is a field that is closely related to the study of post-industrial capitalist urban societies, and has been primarily 
preoccupied with working class cultures. As Jeffrey Hill put it, it has shown a 'concern with the particular, the local, the empirical, the verifiable-by-evidence': all of which make more difficult the study of pre-modern competitive exercise, given the paucity of written rules, records of play, or formal organisations. ${ }^{6}$ The distinction between sports and games - which today gives philosophers some pause - is even more difficult to draw in the late middle ages. ${ }^{7}$ For the purposes of this essay, however, 'sports' seems an appropriate category of analysis under which to classify archery, as in its late medieval form it was played competitively with strict regulations, was practised by formal organisations (guilds) as well as informally, and in large scale competitions was certainly a significant spectator sport. ${ }^{8}$

In this article, I analyse the ways in which the August 1478 archery match - a friendly competition between amateurs - reiterated masculine social norms and strengthened corporate bonds within a fraternity setting. Set in the wider context of the Calais wool merchant community, it provides the perfect example of homosocial enculturation: a culture that crossed age and marital categories, and in so doing, strengthened hegemonic power.

\section{$\underline{\text { The socio-economic context }}$}

The wool merchants living in fifteenth-century Calais were largely all English men, a group of expats whose properties and extended families generally remained on the other side of the Channel. The specific political and economic context that resulted in their extended presence in Calais requires some explanation, particularly since the 
privileges and restrictions that resulted from these generated a very specific social milieu.

Medieval English merchants operated under the system of the Staple. The government required that all overseas trade in certain goods be transacted at specific designated market towns or ports, referred to as the 'staple ports'. At these specified places, merchants were required to submit their goods to inspection, and to pay a levy to the Crown on goods for export to the Continent. Having been won back from the French in 1347, Calais was now an English possession. As the Crown viewed it as an essential asset in ongoing attempts to re-establish a foothold in France, it had the unusual situation of being the site of a permanent garrison. This was not a common occurrence in the late middle ages, when armies would normally be disbanded outside of the campaigning season. The wool Staple's move to Calais was in part intended to cover the high costs of maintaining a permanent military installation. ${ }^{9}$ In the past, staplers' stocks of wool had been seized to pay for the costs of the garrison, or to serve as a 'loan' by York or Lancaster during the Wars of the Roses. By 1466, however, Edward IV and the staplers had come to a formal agreement. The Merchants of the Company of the Staple at Calais were now responsible for paying the wages of the garrison and maintaining the defences of Calais out of the customs and subsidy taxes levied on its members in exchange for a number of concessions. ${ }^{10}$

There is evidence that other merchants began to avoid the Calais Staple's regulations, both through legitimate means (the Merchant Adventurers had their licences renewed to export wool outside the Staple) and illegitimate methods 
(smuggling rose as wool bypassed the Staple on its way to the Burgundian marketplaces). High export taxes and tight regulations made fewer and fewer merchants of prestigious companies such as the Grocers interested in joining the Company, especially since the growing English cloth trade pushed down the demand in Europe for English wool. ${ }^{11}$ By the mid-1470s the Calais fellowship was mostly composed of men of reasonably modest means, such as the Cely brothers whose interest in the wool trade generated them each an income of around $£ 100$ a year. So by the time Rob Adlyn issued his archery invitation in 1478, the average merchant of the Staple made a decent income but could not be termed rich, and often carried substantial debt: indeed, in 1476 the Norfolk gentleman John Paston warned his son not to lend money to the staplers, who were known as 'slack payers'. ${ }^{12}$

It can be difficult to ascertain the precise membership of the fellowship, as most wool merchants were also members of craft guilds and would be designated in official documents by their company affiliation, not their membership of the Staple. However, Alison Hanham has found records of at least 220 active staplers during the period 147489 , though their involvement in the industry varied from shipping a few dozen sackweights of wool every year as a useful financial sideline to other mercantile interests, to a handful of men who shipped over two hundred sack-weights each. Most staplers fell toward the lower end of the scale. ${ }^{13}$

Calais at this time was a town of perhaps four thousand inhabitants. Edward III had expelled the native French population on the town's capture, and through grants of property and promises of privileges the Crown repopulated Calais with English settlers. ${ }^{14}$ 
The Staple was essential to the financial well-being of the town, and indeed to its safety, given its responsibility for paying the garrison. This must have been an enormous financial burden for the staplers, particularly as their overall wealth declined: in the early fifteenth century the annual wages for the garrison amounted to a staggering $£ 16,000{ }^{15}$ Prior to the Company taking responsibility for those wages in 1466 , there had been a repeated cycle of garrison mutinies and royal demands for loans from the staplers. While the new system was much more stable, the way soldiers were to be paid continued to provide points of conflict. The garrison's desire for a ready source of cash could be difficult to satisfy in a town where the coin in circulation came from multiple jurisdictions and its value against sterling was subject to fluctuation. Meanwhile the new arrangement made it easy for the Crown to exert pressure on the wool trade, for instance in 1482 insisting members advanced their exports of wool in order to pay a portion of their customs ahead of time. ${ }^{16}$

Given what they cost it, it is unsurprising that the Company was fiercely protective of its privileges in Calais. This seems to have extended to a suspicion of the intentions of the civic authorities; in 1484 the Staple insisted its members could not both belong to the company and be aldermen of the town, as in their civic roles they would 'observe that in many things contrary to the wealth of the Place'. ${ }^{17}$ While the fellowship as a whole was represented in London by the mayor of the Company, it was at the 'Place' that ordinances were passed and disputes heard, in the Company's own court of law. It was strictly forbidden to disclose any 'secret matter' discussed in this court. Furthermore, according to a chancery petition from 1486, any member who used a writ 
of a superior court to remove a case from the Staple court would be penalised by the Company. ${ }^{18}$ From all this it is clear that, in organisational terms, the Company formed a close-knit, monopolistic cartel, jealous of its privileges, anxious about encroachment from both Crown and town.

Yet although the Staplers might have been insular in terms of their professional outlook, they were not an isolated community. Wool merchants traded in futures as well as on credit; this made them particularly vulnerable to shortages of bullion, which was an ongoing problem from the mid-fourteenth century onward. ${ }^{19}$ To be financially successful despite the restrictions and taxes in place, merchants had to work hard to maintain a continuous flow of trade. Given their dependence on credit, commercial relationships required mutual confidence, and the Calais wool merchants worked hard to maintain relationships with their business partners back in England and on the Continent. These relationships necessarily blurred the line between the social and economic; the reality of medieval business practices meant that personal trust needed to be placed in one's trading partners, even when one had legal protections in place. ${ }^{20}$ Fortunately, Calais' geographical location made it a good base from which to maintain business and social connections. Both the Paston and Cely correspondence make it clear that the journey to Calais from London was not considered particularly onerous or timeconsuming, and post travelled so quickly between the two that correspondence between family and friends was easily maintained. ${ }^{21}$ John Paston II escorted Lord Souche and two young heiresses to the town in 1473 , noting that Calais was a merry town with plenty to keep them entertained, while just outside the town the Pale's marshes 
provided space for hawking and riding that the Celys and their acquaintances so enjoyed. ${ }^{22}$ A town with such a large garrison would be expected to have such amusements, but we might also expect to find an uneasy relationship between the merchants and military men: it was within living memory, after all, that the soldiers had literally held the staplers hostage until their wages were paid. ${ }^{23}$ Surprisingly, however, the garrison barely features in the Cely letters at all - although in late 1480 the gregarious George Cely was acquainted well enough with soldiers that his godfather Will Maryon was worried if war came they might persuade him to join up. ${ }^{24}$ Perhaps the younger generation, at least, had put aside their differences sufficiently that they could socialise with the soldiers in town; in any case, despite occasional disputes over methods of payment, the garrison does not seem to have caused problems for the staplers on a day-to-day level. The wool trade may have increasingly been a challenging industry in which to make a living, but for the merchants of the Staple, life in Calais could be both agreeable and profitable, serving as it did as an entry-point into the economic life of the Continent.

By the late 1470s, the Staple at Calais was populated by an economically conservative, middlingly wealthy elite that was vulnerable to economic crises and as a result was protectionist in outlook. Many of these men would have acquired the freedom of the Staple through their fathers; if a man had been born once his father was a member of the company, his own admission would cost only $40 \mathrm{~d}$. However, in a period when the survival of male heirs could not be taken for granted, there was also always a steady flow of newcomers into the trade. ${ }^{25}$ An increasing number came up through 
apprenticeships, and some were established merchants and officials who paid a high fee to join the company. ${ }^{26}$ Many of them would have split their time between London, Calais, European market places and in some cases, their country estates in England. ${ }^{27}$ They were, in short, from the growing middle class of the fifteenth century: an ambitious and mobile section of the population that, however, felt itself burdened by the demands of the Crown and whose prosperity was constantly threatened by price fluctuations and coin shortages in mainland Europe. ${ }^{28}$

\section{Establishing community}

Earlier work on community within craft guilds in the later middle ages has emphasised the importance of establishing cultural homogeneity within the ranks of the brotherhood. As Margaret Pappano argues, guild activities and legislation were specifically designed to promote fraternity, fining members for quarrelling and for refusing guild duties such as participation in offices and feasts. They worked hard to maintain a corporate, collective identity. ${ }^{29}$ Christina Fitzgerald convincingly demonstrates that guild regulations and activities strengthened individuals' identities as members of a corporate whole, and disciplined them into becoming compliant constituent parts of that body. ${ }^{30}$ Gervase Rosser's work on religious guilds - whose membership often overlapped with craft guilds, though they served different functions - shows that fraternity feasts not only celebrated the prosperity of a community but also promoted it by facilitating group bonding, which was aided by making attendance compulsory. ${ }^{31}$ 
Establishing a collective identity and culture may have been particularly important for the fellowship at Calais. While merchants of all kinds by nature of their profession often had peripatetic lifestyles, the members of the Staple operated in a way that may have particularly relied on social bonds. The Cely family serves as a good example of how the business of the wool trade functioned. One member of a partnership in the wool trade - here Richard Cely senior or sometimes his son Richard junior - would be responsible for visiting their middleman in wool country to examine the samples, agree to a sale and have the wool transported to London. He would oversee the loading of the wool at the port for transport to Calais. Another member of the partnership (in this case, George Cely, Richard senior's youngest son) would receive the wool at the Calais end. This partner would usually be responsible for arranging the practicalities of selling the wool onward from Calais. George seems to have lived semipermanently in Calais, with his elder brother Richard only crossing over occasionally, and his father not at all.

It was more typical for junior members of the partnership to take on the Calais side of the business, but the wool merchants inhabiting Calais were certainly not all young bachelors. However, it seems that the married staplers did not usually bring their families to Calais, and often lived as lodgers of local families if they did not own their own properties there. ${ }^{32}$ The community provided by the fellowship of the Staple may have been particularly valuable to these men living at a distance from their families in England, especially since, as we have seen, the regulations of the fellowship discouraged deeper integration into local Calais life through participation in its civic affairs. In order 
for the socio-economic society of the Staple to function, the bonds between its members needed to be more than superficial ties provided simply by membership of the same profession.

The Cely correspondence that provides the primary source of evidence for these bonds is an incomplete collection of documents covering the period 1472-88. In 1489 a dispute arose between Richard Cely junior and the widow of his brother George Cely, and when the case was brought before the Court of Chancery a mass of letters and memoranda was collected as evidence. The collection forms an incredibly rich source of data about the wool industry and the business of the Staple, which is particularly vital for historians as most of the Company's documents were lost when Calais fell to the French in $1558 .^{33}$ The letters also give great insight into the lives of the Celys, who seem to be quite a typical stapler family in terms of their income and operational structure. By 1478, George Cely was running the Calais end of the business and spent much of the year living there, while his elder brother Richard seems to have spent most of his time in London, with occasional visits to Calais when business demanded it. Despite living for much of the time in separate countries, the brothers clearly had a close relationship and also shared many friends and acquaintances. In the late 1470 s, the brothers were single men probably in their early twenties, though both were married by $1484 .{ }^{34}$ Their father died in 1482 , and from that time onward they seem to have run the business as partners, with George moving back to London and leaving their junior relation William Cely in charge at Calais. ${ }^{35}$ From this point forward, most of the letter collection is composed of letters from William to George. Prior to this, however, the bulk of the correspondence 
is between Richard junior and George, and their fraternal bond, friendship and shared economic interests mean that their letters reveal insights into a close-knit mercantile community. The collection also contains a number of letters from colleagues in the wool trade that provide evidence not only of everyday business but also of the social possibilities offered by life in Calais and as a member of the Company.

The letters make it clear that the stapler community relied on informal networks of communication and mutual favours to enact business and to take care of personal matters. The two often bled together. George Cely went very frequently to the great markets in Antwerp and Bergen-op-Zoom. They were long, laborious journeys, and so were unlikely to be made unless one had a business need to go - but those who were going found themselves inundated with requests for purchases from their fellow staplers. In September 1480, the stapler Edmund Bedingfeld wrote asking his 'right special friend' George to buy him a:

long gown of camlet, damask or satin, that be not but a small price of four nobles or there about. I pray you buy me one, but I had rather have camlet, if it be black, tawny or violet, but no other colour.

This rather particular request was followed by a list including ladies' gloves, archery equipment and daggers! The use of the term 'friend' in a medieval letter in itself does not necessarily indicate a particularly close relationship, but certainly there must have been a measure of trust between the two men for Bedingfeld to make such a request 
and to expect that his goods would be delivered 'to Lynne or to Bolton with my gear that Bondman sends. ${ }^{36}$

This person, William Bondman, appears a number of times in the Cely correspondence. In this instance, evidently he also had goods to send to Bedingfeld that could be shipped across with George's purchases. This probably was not a very onerous task, as King's Lynn was England's third most important port and Cely and Bondman would have plenty of experience shipping goods there. Nonetheless, the request relies on George's good will toward Bedingfeld and on his acquaintance with Bondman, while the casual way Bedingfield references 'his gear' suggests that Cely already knew what other task Bondman was performing for him.

The Celys and William Bondman seem to have been on friendly terms for a number of years. In a letter of August 1478, Richard Cely junior wrote from Calais to George who was away on business in Bruges:

I have been to seek your black gown at Redhood's, and it was at Bondman's, and I have received it and put it in your chest... ${ }^{37}$

That George was not sure where he left his gown may suggest regular visiting of friends' and colleagues' houses. George evidently trusted Bondman, because in memoranda of 1480 written for a friend who will be receiving wool on his behalf, he noted that either John Elderbeck or William Bondman would have the key to the woolhouse. This is no doubt partly a practical arrangement, as the woolhouse was next door to William's. However, a note that extra fells (wool-bearing skins) belonging to the Celys' friend 
William Maryon were stored alongside Bondman's fells suggests a mutually cooperative relationship that went beyond the convenience of neighbourliness. ${ }^{38}$ William Bondman's assistance here seems characteristic of behaviour amongst merchants of the Staple at Calais. Taking delivery of goods and other time-sensitive tasks could be disrupted if one needed to be away on business, which for staplers frequently involved trans-continental or trans-Channel travel. Whilst no doubt these merchants made use of their servants in ensuring tasks were carried out, they also called on their friends and colleagues, safe in the knowledge they could expect to repay the favour at a later date.

But as we saw with Edmund Bedingfield, these ties of neighbourly obligation could translate into assistance not directly related to the work of the mart. William Bondman once again crops up in a letter of May 1482 from William Cely to George, who was in Bruges. Bondman, though at the time in Calais, apparently had a horse stabled at the Starre Inn in Bruges, and William Cely let George know that Bondman was willing to loan George his horse to come home on if he had need of it. The Celys had already dispatched the horse belonging to their friend Thomas Hayward, but "he [the horse] is but little: and if it be not big enough you may have William Bondman's horse.' This solicitous behaviour was in response to George's ill-health. As William Cely wrote at the closing of his letter:

I beseech Almighty Jesus keep you and bring you well to Calais, for here are many of your good friends that be sorry for your great sickness. ${ }^{39}$ 
It seems unlikely to me in this context that William was using 'friend' in the commonplace medieval way of acknowledging an acquaintance of similar or lesser standing. Instead he was talking about good friends - the kind of friends who would send a horse all the way to Bruges to help a sick young man get home.

George may have caused his friends particular concern with regards to his health. In a letter of early 1478 George wrote a letter to his father saying his return to Calais was welcomed by friends who had feared him dead, though it is unclear whether he means this was because of illness or perhaps an accident en route:

I came into Calais the Thursday after my departing from you, in safety I thank God, and I was welcome unto my friends, for until my brother came to Calais there was no other tidings there but I was dead. ${ }^{40}$

It seems likely based on the people who otherwise populate the letters that these 'friends' were George's fellow staplers. George was seriously ill again in late 1479, and amongst anxious missives from his family there are also several letters from his fellow staplers that send him good wishes for his recovery. ${ }^{41}$ At the start of November Ralph Lemynton hoped to 'hear of your good welfare, the which I beseech almighty God increase to his pleasure', while at the end of the month Thomas Kesten said that he 'understood that you have been sore sick and are now well revived, in the which Jesus comfort you and make you strong for his mercy'. ${ }^{42}$

Despite these several periods of poor health, George Cely seems to have built strong ties with many members of the Company. The letters he exchanged with his 
fellow stapler John Dalton provide rare documentary evidence for a genuine friendship between two young medieval men. In February 1479, Dalton wrote to Cely with some information about fells he had sold on behalf of Richard Cely senior and some other merchants, before getting to the real meat of the letter:

I pray you that I may be recommended unto your brother Richard Cely, and God knows we greatly miss you. I had rather than the best gown I have that you might abide still here with us. You shall understand more at your coming - it is of mirth the cause I would have you for.

The note finishes with a message from the master lieutenant of the Company - that Cely and William Dalton (John's brother), in their posts as treasurers, had used up a cask of wine left by the previous treasurer and not replaced it. ${ }^{43}$ This short letter manages to encapsulate many key business and social elements of Staple life: cooperation rather than competition in the marketplace, including carrying out buying and selling on other staplers' behalf; the everyday duties of the Company, which because of Calais's particular situation resulted in younger merchants often playing central roles in its administration; and genuinely affectionate friendship.

Cely and Dalton were still friends in January 1482, when the latter wrote a quietly sympathetic letter to the former on the loss of his father, while also imparting some sensitive information:

I have received two letters from you, by the which letter I understand of your great heaviness of your father, on whose soul God have mercy. ... Also sir, ... in the 
reverence of God take it patiently and hurt not yourself, for that which God will have done no man may be against. ... Also sir, where we ate the good puddings, the woman of the house that made them, as I understand she is with child by my brother that had my Irish dagger.

Dalton's condolences here go beyond mere platitudes into a real concern for Cely's welfare. His circuitous message at the end of the letter, meanwhile, was subtly informing Cely that he had fathered a child. The strangely-phrased sentence about 'good puddings' would seem on first reading to be about some other member of the Company ('brother' being a term the staplers used for one another), but shortly after this letter George received another from his servant Joyce Parmenter, who laconically informed him that 'I let you know, where you go and eat puddings the woman is with child, as I understand. ${ }^{44}$ Two such similarly worded letters could only be intended to let George know that he was going to be a father. The deliberately vague language probably points to some need for discretion; I have argued elsewhere that there was a good deal of social toleration for young men having amorous encounters, but that siring an illegitimate child was still a potential embarrassment. ${ }^{45}$ Seven months after Dalton and Parmenter wrote to George, William Cely sent him a letter informing him that a certain Margery has asked him to tell George she needed clothing for her churching, which would be an unusual request if she were not the mother of his child. ${ }^{46}$

The August date of this letter makes it extremely likely that 'Margery' was the woman of the pudding house that Dalton and Parmenter wrote about. In Middle English, 'pudding' was used to mean both ale and a type of sausage: the conflation of the food 
stuff and a drink may suggest the context in which such 'puddings' were sold. Margery may well have worked in a tavern or alehouse that served this kind of cheap meal in addition to ale. Women had a significant presence in the brewing and selling of ale, resulting in an anxiety on the part of the authorities about female-run taverns as potential sites of sexual licence and violence. ${ }^{47}$ Thus, just as foodstuffs and drinks became conflated, so too did alehouses and brothels, and customers become purchasers of distinct but associated 'products'. Of course, this is not to say that the pudding house George frequented was actually a brothel. It was probably not, but we do get a sense that taverns were places where men could find sex and where womenwhether 'professional' sex workers or not - might solicit. This gives us a context for a way in which a young unmarried man might meet a woman and get her pregnant. Two young men like Cely and Dalton, at some distance from their natal homes and possessed of a decent income, could easily be imagined to spend their leisure time in all kinds of 'mirth': including the sort that got women in trouble. ${ }^{48}$

\section{Mixed age socialising and the archery match}

In the emergent area of studies in homosociality, the relationship between two or more men of this type - young, unmarried and from an elite background - has been the focus of research. From historians of the middle ages writing about socialising amongst apprentices, to social scientists discussing bonding in fraternities, one of the key assumptions in much analysis of homosocial environments is that we are talking about men of a similar age and marital status. ${ }^{49}$ Yet for medieval men, many formallystructured homosocial environments - the monastery, orders of chivalry, craft guilds - 
would necessarily have been made up of men ranging from youths to seniors, and often brought married and unmarried men together. These types of organisations were, of course, ideal environments in which to establish and perpetuate hegemonic norms about gendered behaviour and social power.

Rob Adlyn's 1478 invitation from the wedded men of the Company to its bachelors to compete in an archery match offers an example of how cross-age socialising could both acknowledge differences between men at different stages of life, whilst reinforcing their solidarity as members of a group. This begins with the form of the invitation itself. As this is the only document of its kind I have come across, it is difficult to tell how typical it is, though the structuring of the text has the feel of a formula in the same way that Middle English letters are clearly organised along principles schooled into their writers at a relatively elementary level. ${ }^{50}$ The dorse features a fine seal of a laurelwreathed head and the initials of the author of the letter: R.A. ${ }^{51}$ Most of the letters in the Cely collection have no seals, and if they have anything on the dorse beyond the direction instead feature a hand-drawn representation of the sender's device. As most of the letters are between the brothers George and Richard Cely junior, perhaps a seal would have seemed like an unnecessary flourish. Their father's letters, however, often bore a seal and virtually always a hand-drawn device of a shield, which might suggest the use of a seal could both indicate the sender's status and the hierarchical relationship between sender and recipient. ${ }^{52}$ It might be because the invitation was addressed to the bachelors, from the married and potentially more senior men of the Staple, that it seemed appropriate for Adlyn to seal the letter, just as Richard Cely senior sealed his 
communications to his sons. It could also be that Adlyn was writing the missive in some official Staple capacity, which could give this seemingly-casual invitation a significance that warranted the use of a seal.

The invitation frames its challenge by addressing 'your order' of bachelors. This could just mean 'rank', but seems more likely to be a playful reference to the group of bachelors being like an order of chivalry. Wedlock was sometimes referred to as an 'order', and interestingly 'bachelor' was sometimes used as a term for an aspirant to the knighthood, as in the romance Arthur and Merlin: 'Po was per made a turnament ... Of bacheler \& 3ong kni3t. ${ }^{53}$ In the invitation the reference was obviously facetious, but it did help to create a distinction between the unmarried men and the married men that could suggest some gentle teasing from the men of the 'order of wedlock' based on the 'order of bachelors' being young and unproved. On the other hand, it also connected both sides: through these fictitious 'orders' and through the invitation being from men of the Staple to other men identified as being freemen of the Staple, it emphasised that their differences only goes so far.

These playful 'orders' had literary precedents in Arthurian legends that may have been familiar to the staplers. For example, in Thomas Malory's Morte Darthur, which brought together multiple versions of largely French romances into a new English telling, King Arthur loses eight of the Round Table's knights and Sir Pellinore notes that there are 'in youre courte full noble knyghtes bothe of olde and yonge' ${ }^{54}$ His suggestion that half the places are filled with young knights, the other half with mature knights, is accepted without question by Arthur as the sensible approach to producing a balanced 
Round Table. A court needs young, energetic warriors and older, experienced knights in order to function as a socially and politically powerful unit.

The Round Table, a homosocial elite at the heart of the Arthurian court, seems far removed from a busy Calais mercantile community. But in both settings, the politically or economically determined membership of the group resulted in a homosocial society of elite men, connected to one another firstly by an oath of loyalty to the organisation as a whole, and then by personal ties of friendship. Scott Kiesling argues that men share a cultural discourse where 'men are understood normatively to want (and need) to do things with groups of other men', ${ }^{55}$ which makes a social event like the Calais archery match seem like it simply naturally happens, even when it has taken planning. There does not seem to be anything exceptional about a group of colleagues playing a game together: except that the mix of men here is different from the type usually discussed in analysis of same sex environments. Rob Adlyn's challenge from the married men to the bachelors provided an easy division point of the men of the Staple into two distinct categories. But from what we know of mercantile marriage patterns, this categorisation was both temporal and temporary. That is, most men would marry at least once, for the first time usually in their early to mid-twenties.

George Cely and his brother Richard were probably around 25 or 26 when they married, in 1483 and 1484 respectively, having been actively looking for wives for a couple of years. Membership of the Order of Bachelors usually involved graduation to the Order of Wedlock as part of both growing older and becoming more settled in the profession of which all these men were a part. ${ }^{56}$ In the late medieval life cycle, marriage 
was as much a key threshold moment for men as it was for women. According to the philosophical schematic framing of the medieval life course, known as the 'Ages of Man', as a youth transitioned into manhood his impetuous personality traits matured into temperance, reason, and willingness to found a family. It was very often through marriage that a young man gained the economic resources to become a householder in his own right, which was a key element of being socially recognised as a mature man. ${ }^{57}$ The distinction between the bachelors and the married men of the Staple was a friendly one because it was permeable. The married men had all previously been bachelors; almost all of the bachelors would eventually be married men. What this categorisation into teams for a game allowed was the competition that scholars have traditionally seen as a key component of homosocial interaction, while also encouraging the group bonding and reminder of sameness that modern scholarship considers a key component of homosociality.

Research on contemporary homosociality emphasises the key roles of solidarity and communality in forming meaningful bonds between groups of men. Scott Kiesling argues that the American men he studies use linguistic and social strategies to create ties of solidarity, fidelity and friendship between members of a specific privileged group for their mutual benefit. ${ }^{58}$ This is particularly effective in informal social situations. As Virginia Fisher and Sue Kinsey note, in contemporary academia informal networking between men with 'shared masculine interests and values' provides a significant bar to women, who find it difficult to penetrate the social circle generated by male homosocial bonding. ${ }^{59}$ Patricia Yancey Martin asserts that modern businessmen mobilise 'affiliating 
masculinities' in order to align themselves with other men for reasons of personal or collective gain. Men may perform affiliating masculinities through, for instance, workplace banter - humorous discourse that marks them as sharing similar values. At the same time, these social opportunities also offer places for men to make professional connections that may be denied to women who are not included in these conversations. ${ }^{60}$

Of course, the all-male environment of the Staple did not need to exclude women covertly, but their affiliating activities were still exclusionary: according to the invitation, only freemen of the Staple were invited to participate. While the invitation distinguished between bachelors and married men, they were collectively recognised as sharing an exclusive status that had been granted either through birth right, payment or a years-long apprenticeship. ${ }^{61}$ The archery match thus generated a collective identity through deliberately excluding others who would have been involved in the wool trade in Calais - junior apprentices not yet received into the freedom of the Staple, servants and other employees, for example. ${ }^{62}$ The staplers had to reinforce their collective identity not against the incursion of women, but in the face of a competitive marketplace that was threatening their hold on a business with diminishing financial value. Steven Arxer has argued for the existence of 'hybrid hegemonic masculinity' in male-dominated university drinking environments where hypermasculine behaviours most typically associated with young men, such as getting drunk and hitting on women, are enmeshed with - rather than contrasted to - mutually supportive, emotionally open homosocial bonding. ${ }^{63}$ That is, men can participate in competitive masculine 
performances that depend upon affective bonds between the participants to ultimately reinforce the cohesion of their social group. This idea of hybridity is valuable in studying medieval men, because it suggests that mutuality and affection are essential elements of hegemonic masculinity. Hegemonies are often understood through the lens of the people they oppress; but of course power structures cannot function if socially dominant groups are not cohesive.

Given the central role of sports in establishing modern male identity, it is unsurprising that writers in the field of sports science have led many contemporary discussions about homosocial cultures. In the 1990s, the default scholarly assumption was that 'the dominant form of masculinity in sporting cultures is destructive to the body and denies emotional intimacy'. ${ }^{64}$ This mirrored work by scholars in the then-nascent field of studies in masculinities, which tended to emphasise the key features of hegemonic masculinity as 'hypermasculine bravado and posturing, ... domination of women and other men through act and language, drinking to excess, [and] sexual conquest. $^{65}$ More recent work, however, has focused on the shared intimacy and reciprocity that can be offered by even - or perhaps especially by-violent contact sports like boxing. The sheer physical proximity of sparring can easily be understood to result in somatic intimacy, but what kind of intimacy is offered by a non-contact sport like archery ${ }^{66}$

In many ways, despite its lack of physical aggression, archery is the kind of sport that fits older models of discussion of the value of male sports: it allows an individual to prove their pre-eminence over all men in the competition, and provides a scoring system 
that allows for a detailed ranking of players to be provided, placing players firmly within a hierarchy of performance. Successive governments in England treated archery not as a sport but as an obligation for all men because of its function in national defence, establishing its central role in proving masculine prowess. During the fourteenth and fifteenth centuries, several laws were passed which prohibited many field sports and other games in an effort to promote archery practice. Laws enforcing archery practice continued well into the Tudor period. ${ }^{67}$ As a competitive sport played by individuals, archery does not seem to even offer the benefits of a team sport with a lower level of physical contact, where somatic intimacy is replaced by a corporate intimacy provided by identification with the team.

In this period, however, archery guilds were a staple feature of many European towns, and these defensive organisations also became sites of devotional activity and community bonding. These guilds often competed against guilds from other towns, allowing competition to become a way of reinforcing their corporate, collective identities. ${ }^{68}$ In a similar way, the staplers cleverly turned individual competition into a team event. The players competed not for individual glory, but for their 'order', either bachelors or married men, with the aim of winning dinner paid for by the losers. This is a sophisticated level of homosocial interaction: it allowed for competition whilst also encouraging team solidarity, and with the prize being a dinner shared between both winners and losers, it subtly underlined the message that ultimately the division between the two teams was less important than the shared social experience of playing a sport and then dining together. 
The shared meal was a vital element of this; without it, the division between the bachelors and married men would remain open. The archery match allowed the staplers to playfully acknowledge their differences, but it was the dinner that reminded them of their collective identity. There has been much written on the importance of communal dining in guild experience in the middle ages, with for instance Gervase Rosser noting the 'ideology of fraternal harmony' being 'realized in the proceedings of the communal dinner'. ${ }^{69}$ The formal feasts of both craft and religious guilds was not only a celebration, but also a reinforcement of, corporate values and identity. Eating together made a vow of brotherhood somehow tangible; collective consumption provided collective identity, too. ${ }^{70}$ However, most discussion of this type has focused around formal feasts. The example of the staplers points to group socialising taking place outside that set down in guild ordinances and seems more likely than the annual feast to reflect the everyday reality of corporate socialising, much as in a modern context there is likely to be more opportunity for group bonding in businessmen visiting the golf course together than at the firm Christmas party, despite the latter's symbolic significance. This informal socialising is both a reflection and a reinforcement of the ties already present between the men of the Company. Were William Bondman and George Cely as good friends in 1478 as they were in 1482, when Bondman offered Cely his horse to get him all the way home from Bruges? The lack of records prior to 1478 unfortunately mean it is impossible to know. But it does not seem like mere speculation to consider that activities such as the archery match strengthened both their specific friendship, and the ties of community between the men of the Company as a whole. 


\section{Conclusion}

Sports have typically been seen as a location for a stereotypical hegemonic masculinity based on divisive competition, where the struggle for dominance requires a victor. What happened in Calais in 1478 was more complex, but no less reinforcing of hegemonic social norms: an elite masculine culture, the company of the Staple, was celebrated through a complex blending of competition, collaboration and ultimately reintegration into a corporate whole.

The best way to see this unity may be when the staplers had cause to close ranks. In January 1482, a dispute over the ownership of a woolhouse quickly turned quite literally to shit, as a certain Bottrell broke a window of the Celys' woolhouse and threw dung through it. George Cely's servant Joyce Parmenter paid a man to get rid of the dung, but Bottrell assaulted him and took his pitchfork from him. Quick-thinking Parmenter invited four of Cely's fellow staplers to breakfast to witness the damage to Cely's fells 'that they might bear witness another day'. ${ }^{71}$ The Cely household, even in the absence of its master, knew to draw upon the social connections of the stapler community to protect itself. The invitation to breakfast is interesting: perhaps Parmenter thought it would make the men more enthusiastic about coming over in the early morning to help. In any case, it was another kind of casual meal that drew together the stapler community, this time in service of one of their members. As for what resulted from that meeting: later that year Bottrell was ordered by the Porter of Calais to quit the city. This was a serious punishment unlikely to have been provoked simply by an act of vandalism and assault of a lower-status man. Nonetheless, Bottrell was ousted and 
William Cely observed that the ownership of the woolhouse should now be secure. ${ }^{72}$ The men of the Staple might compete against one another in friendly games and in business, but they would close ranks to defend one of their own. In this context, casual sports can be seen as an important component of establishing an elite male group identity that could weather economic and political uncertainty and would fight together to defend its privileges from the incursions of town and crown. 


\section{NOTES AND REFERENCES}

${ }^{1}$ My thanks to The Leverhulme Trust and the Faculty of History, the University of Oxford, for funding the research project of which this forms a part.

${ }^{2}$ All Middle English translations are my own. A 'tailor yard' is a cloth measurement of thirty-six inches. The 'dorse' is the folded back of a letter on which the direction was written. The Cely Letters: 1472-1488, ed. Alison Hanham, Early English Text Society, O.S. 273, London, 1975, no. 29, pp. 26-27. Hereafter CL.

${ }^{3}$ R.W. Connell, Masculinities, $2^{\text {nd }}$ edn, Cambridge, 2005, p. 54, and further discussion pp. 30, 35-6, 57, 80-1. See also Michael A. Messner, Power at Play: Sports and the Problem of Masculinity, Boston, 1992; Masculinities, Gender Relations and Sports, ed. Jim McKay, Michael A. Messner and Don Sabo, Thousand Oaks, CA, 2000; Timothy Jon Curry, 'Fraternal Bonding in the Locker Room: A Profeminist Analysis of Talk About Competition and Women', in Men's Lives, ed. Michael S. Kimmel and Michael A. Messner, $5^{\text {th }}$ edn., Boston, 2001, pp. 188-201.

${ }^{4}$ There has been a good deal written about games, particularly in the context of youth or gender relations. See for instance: Nicholas Orme, Medieval Children, New Haven and London, 1996, pp. 176-83, Hollie L.S. Morgan, Beds and Chambers in Late Medieval England: Readings, Representations and Realities, Woodbridge, 2017, pp. 116-21, Barbara A. Hanawalt, Growing Up in Medieval London: The Experience of Childhood in History, Oxford, 1993, pp. 78-80 and 114-18, and Games and Gaming in Medieval Literature, ed. Serina Patterson, New York, 2015. Such texts usually cite physical sports as a significant feature of the (particularly youthful) male life cycle, but have limited discussion of their functions within communities. On jousting's role in establishing masculine identity, see Michael Bennett, 'Military Masculinity in England and Northern France c. 1050 - 1225', in Masculinity in Medieval Europe, ed. Dawn M. Hadley, London, 1999, pp. 78-79. On homosocial bonding in tournament sports, see Louisa Olga Fradenburg, City, Marriage, Tournament: Arts of Rule in Late Medieval Scotland, Madison, 1991, p. 122, Ruth Mazo Karras, From Boys to Men: Formations of Masculinity in Late Medieval Europe, Philadelphia, 2003, pp. 48-49, and Rachel E. Moss, "'And much more I am soryat for my good knyghts": Fainting, Homosociality, and Elite Male Culture in Middle English Romance', Historical Reflections 42:1, 2016, p. 106.

${ }^{5}$ Robert Edelman and Wayne Wilson, 'Introduction', in The Oxford Handbook of Sports History, ed. Robert Edelman and Wayne Wilson, Oxford, 2017, p. 6.

${ }^{6}$ Jeffrey Hill, 'British Sports History: A Post-Modern Future?', Journal of Sport History 23:1, spring 1996, p. 14.

7 The philosophy of sports emerged in the 1960s and is now a well-established subfield - see Routledge Handbook of the Philosophy of Sport, ed. Mike McNamee, William J. Morgan (London and New York, 2015) for an excellent introduction. Heather Reid gives a good overview of the scholars who have attempted to answer 'what is sport?' in her Introduction to the Philosophy of Sport, Lanham, Maryland, 2012, pp. 31 - 55. In Reid's view, sports are ultimately summed up as 'rule-governed activities - 
something perhaps better understood as social practices' (p. 55). With such a definition, the value for historians in studying sports is also clear.

${ }^{8}$ The elements of competition and regulation seem essential to all scholarly definitions of sports, with competition being the key element used to distinguish them from games. Edelman and Wilson ('Introduction', The Oxford Handbook of Sports History, p. 6) emphasise the significance of activities that specifically aim to attract spectators. Bernard Jeu - perhaps somewhat eccentrically - insists on the necessity of the outdoors, which might give pause to fans of indoor sports. (Bernard Jeu, 'What is Sport?', Diogenes 20: 80, 1972, pp. $150-163$, especially p.151.) I discuss the evolution and practice of medieval archery more extensively at $\mathrm{pp} .[\mathrm{X}]$.

9 Pamela Nightingale, A Medieval Mercantile Community: The Grocers' Company and the Politics and Trade of London, 1000 - 1485, New Haven and London, 1995, p. 216, and Susan Rose, Calais: An English Town in France 1347-1558, Woodbridge, 2008, pp. 32-33.

${ }^{10}$ Alison Hanham, The Celys and Their World: An English Merchant Family of the Fifteenth Century, Cambridge, 1995, pp. 224-25; Nightingale, Medieval Mercantile Community, pp. 527-28.

${ }^{11}$ Jenny Kermode, Medieval Merchants: York, Beverley and Hull in the Later Middle Ages, Cambridge, 1998, p. 168.

12 Paston Letters and Papers of the Fifteenth Century, ed. Norman Davis, Vol. 1, 1971, p. 496.

${ }^{13}$ Nightingale, Medieval Mercantile Community, pp. 528-9, Hanham, Celys and Their World, p. 417, pp. 242-45.

${ }^{14}$ Rose, Calais: An English Town in France, pp. 23-4.

${ }^{15}$ Susan Rose, The Wealth of England: The Medieval Wool Trade and its Political Importance 1100-1600, Oxford and Philadelphia, p. 147.

${ }^{16}$ Rose, Wealth of England, pp. 152-54.

17 'The Place' was the Staplers' hall in Calais. William Cely to Richard and George Cely, 29 February 1484, CL no. 209, p. 200.

${ }^{18}$ Hanham, Celys and Their World, pp. 240-42. Unfortunately the record is mutilated and it is not possible to tell what the penalty was. Public Record Office, London, C.1 $82 / 102$.

${ }^{19}$ Kermode, Medieval Merchants, p. 198.

${ }^{20}$ Kermode, Medieval Merchants, 201, 227.

${ }^{21}$ Letters could be sent between London and Calais in well under a week. Rose, Calais: An English Town in France, p. 110.

22 Rose, Calais: An English Town in France, pp. 92-3.

${ }^{23}$ This incident happened during the garrison mutiny of 1454; similar events had taken place in 1406, too. Rose, Wealth of England, pp. 150-51.

${ }^{24} C L$, no. 110, pp. 98-99.

${ }^{25}$ Kermode, Medieval Merchants, pp. 78-9. Kermode demonstrates that in London in the period $1318-1497$, between $16 \%$ and a staggering $49 \%$ of orphans left by merchants died before reaching the age of 21. ${ }^{26}$ Hanham, Celys and Their World, pp. 248-9. 
${ }^{27}$ The Celys, for instance, had a country estate in Aveley, Essex, and also owned properties in Rainham and Upminster. Hanham, Celys and their World, p. 8.

28 Jenny Kermode gives a good overview of the impact of bullion shortage on the wool trade. Kermode, Medieval Merchants, pp. 165-6.

${ }^{29}$ Margaret Aziza Pappano, "'Leve Brother": Fraternalism and Craft Identity in the Miller's Prologue and Tale', in Reading Medieval Culture: Essays in Honor of Robert W. Hanning, ed. Robert M. Stein and Sandra Pierson Prior, Notre Dame, 2005, pp. 251-53. ${ }^{30}$ Christina Fitzgerald, The Drama of Masculinity and Medieval English Guild Culture, London, 2007, p. 29.

${ }^{31}$ Gervase Rosser, 'Going to the Fraternity Feast: Commensality and Social Relations in Late Medieval England', Journal of British Studies 3:4, 1998, pp. 430 - 446.

32 Rose, Calais: An English Town in France, pp. 100-1, 105. George Cely lodged with 'Bornell's widow' from sometime before July 1478 to at least the following summer; he seems to have had his own house by 1481 . $C L$, no. 28 , p. 26; no. 55, pp. 50-51; no. 142, pp. 129-30.

${ }^{33}$ Rose, Wealth of England, p. 76.

${ }^{34}$ On the brothers' ages, see Hanham, Celys and Their World, p. 8, p. 30. On George and Richard's relationship, see Rachel E. Moss, Fatherhood and its Representations in Middle English Texts, Woodbridge, 2013, p. 40, pp. 171-72.

${ }^{35}$ William Cely's precise relationship to the family is not known; despite their shared surname, he is never referred to as a relative, and he writes to all the family members with great deference. $C L$, 'Introduction', pp. x-xiv.

${ }^{36} C L$ no. 103, p. 90 . 'Camlet' is a woven fabric made from goat's hair.

${ }^{37} C L$ no. 32, p. 29. The other man is probably a 'Thomas Redewhode', burgess of Calais, who witnessed a lease for George in 1481.

${ }^{38}$ CL no. 105, pp. 92-93.

${ }^{39} \mathrm{CL}$ no. 170, p. 158; Hanham, Celys and their World, p. 61.

${ }^{40}$ George Cely to Richard Cely senior, 12 March 1478, CL no. 45, p. 42. Hanham dates this letter as $1478 / 9$, but 1478 seems more likely to me.

${ }^{41}$ George was extremely ill in October and November 1479, as multiple letters from his friends and family attest. $C L 67,70,71,73,74,76,78,80,81$, pp. 60-72.

${ }^{42} C L$ no. 72, p. 64 , and no. 76, p. 67.

${ }^{43}$ CL no. 44, pp. 41-2.

${ }^{44} C L$, no. $142,130$.

${ }^{45}$ Rachel E. Moss, 'An Orchard, A Love Letter, and Three Bastards: The Formation of Adult Male Identity in a Fifteenth-Century Family' in What is Masculinity? Historical Dynamics from Antiquity to the Contemporary World, ed. John H. Arnold and Sean Brady, London, 2011, pp. 226-44.

${ }^{46} \mathrm{CL}$, no. $181,167$.

47 Jane Laughton, 'The Alewives of Later Medieval Chester', in Crown, Government and People in the Fifteenth Century, ed. Rowena E. Archer, Stroud,1995, p. 202, Judith M. Bennett, Ale, Beer, and Brewsters in England: Women's Work in a Changing World, 1300-1600, New York and Oxford, 1996, p. 122, Ruth Mazo Karras, Common Women: Prostitution and Sexuality in Medieval England, New York: Oxford University Press, 1996, pp. 54-55. 
${ }^{48}$ For more extensive discussion of this incident, see my article 'An Orchard, A Love Letter, and Three Bastards', in which I explore the central role of premarital sexual encounters in establishing young men's masculine identities. I also argue that 'pudding' may have become shorthand slang for sexual intimacy, making Dalton and Parmenter's remarks more loaded than they may initially appear. See also Moss, Fatherhood and its Representations, pp. 173-5.

${ }^{49}$ On apprentices' socialising, see Karras, From Boys to Men, pp. 128-29, Hanawalt, Growing Up in Medieval London, pp. 114-29, and P.J.P. Goldberg, 'Masters and Men in Later Medieval England', in Masculinity in Medieval Europe, ed. Hadley, pp. 63-67. On social bonding between young men in contemporary society, see for instance Curry, 'Fraternal Bonding in the Locker Room', pp. 194-5, Clifton Evers, 'Intimacy, sport and young refugee men', Emotion, Space and Society 3, 2010, pp. 56 - 61, Scott Fabius Kiesling, 'Homosocial desire in men's talk: Balancing and re-creating cultural discourses of masculinity', Language in Society, 34, 2005, pp. 695 - 726, and Steven L. Arxer, 'Hybrid Masculine Power: Reconceptualizing the Relationship between Homosociality and Hegemonic Masculinity', Humanity \& Society 35, 2011, pp. 390 - 422.

${ }^{50}$ For more discussion of the composition of medieval English letters, see Malcolm Richardson, Middle-Class Writing in Late Medieval London (London: Pickering \& Chatto, 2011), pp. 132-3, and my Fatherhood and its Representations, pp. 74-81. ${ }^{51}$ S.C.I 59/47

52 For Richard Cely senior's seal, see for instance Public Record Office, London, S.C.I 53/157.

${ }^{53}$ Of Arthour and of Merlin, ed. O.D. Macrae-Gibson, Early English Text Society O.S. 268, 279, London, 1973, 1979, II. 3585-7.

${ }^{54}$ Thomas Malory, Malory: Works, ed. Eugène Vinaver, Oxford, 1971, p. 80.

55 Kiesling, 'Homosocial desire in men's talk', p. 696.

56 Urban and landed elites alike saw sons typically marrying for the first time between the ages of 21 and 26. Peter Fleming, Family and Household in Medieval England, Houndmills, 2001, p. 22.

${ }^{57}$ On the Ages of Man as a schematic framework, see J.A. Burrow, The Ages of Man: $A$ Study in Medieval Writing and Thought, Oxford, 1996. On its influence on popular thought, see P.J.P. Goldberg, 'Life and Death: The Ages of Man', in A Social History of England, ed. Rosemary Horrox and W.M. Ormrod, Cambridge, 2006, 413. I discuss the shift from adolescence to manhood in Fatherhood and its Representations, pp. 41 - 50. The economic value of marriage in allowing men - of many socio-economic backgrounds - to set up their own households is well-established in scholarship: see for instance Ruth Mazo Karras, From Boys to Men: Formations of Masculinity in Late Medieval Europe, Philadelphia, 2003, pp. 144-48 and Patricia Simons, The Sex of Men in Premodern Europe: A Cultural History, Cambridge, 2011, pp. 188-9. Kermode (Medieval Merchants, pp. 76 - 87) and Pappano ('Fraternalism and craft identity', pp. 251 - 5) discuss the significance of marriage in allowing merchants and craftsmen to establish themselves both financially and in terms of finding a place within business networks.

${ }^{58}$ Kiesling, 'Homosocial desire in men's talk', particularly pp. 712-18. 
${ }^{59}$ Virginia Fisher and Sue Kinsey, 'Behind closed doors! Homosocial desire and the academic boys club', Gender in Management 29:1, 2013, pp. 48-49.

60 P.Y. Martin, 'Mobilising masculinities: women's experiences of men at work', Organization 8:4, 2001, pp. 602-05.

61 Hanham, Celys and their World, pp. 247-50.

62 The letters make it clear that senior apprentices would often be made free. For instance, Richard Cely senior asks that Thomas Folborne should be made free as he was within three years of completing his eight-year apprenticeship. $C L$, no. 13, p.12. ${ }^{63}$ Arxer, 'Hybrid Masculine Power', especially pp. 404-18. The term 'hybrid hegemonic masculinity' was coined by Demetrakis Z. Demetriou in 'Connell's Concept of Hegemonic Masculinity: A Critique', Theory and Society 30:3, 2002, pp.327 - 61.

${ }^{64}$ Laurence de Garis summarises and critiques this perspective in his " Be a buddy to your buddy": Male identity, aggression, and intimacy in a boxing gym', in McKay, Messner and Sabo, Masculinities, Gender Relations and Sports, p. 89.

${ }^{65}$ Allen Klein, 'Dueling Machos: Masculinity and Sport in Mexican Baseball', in McKay, Messner and Sabo, Masculinities, Gender Relations and Sports, p. 68.

${ }^{66}$ On somatic intimacy, see Garis, 'Be a buddy to your buddy', p. 97.

${ }^{67}$ On archery in everyday life, see Steven Gunn, 'Archery Practice in Early Tudor England', Past and Present 209, 2010, pp. 53 - 81, Paul B. Newman, Daily Life in the Middle Ages, Jefferson, NC and London, 2001, p.165, and Roberta Gilchrist, Medieval Life: Archaeology and the Life Course, Woodbridge, 2012, p.56.

${ }^{68}$ See Laura Crombie's Archery and Crossbow Guilds in Medieval Flanders, 1300 - 1500, Woodbridge, 2016, especially pp. 159 - 89.

${ }^{69}$ Rosser, 'Going to the Fraternity Feast', p. 433.

${ }^{70}$ For more discussion on the role of feasts in guilds, see Laura Crombie, 'Honour, community and hierarchy in the feasts of the archery and crossbow guilds of Bruges, 1445-81', Journal of Medieval History 30, 2011, pp. 102-113.

${ }^{71} C L$ no. 142 , p. 130 . See also John Dalton's letter regarding the same matter, $C L$ no. 141, pp. 128-9.

${ }^{72} \mathrm{CL}$ no. 185 , p. 170. His comment about this is somewhat opaquely worded - 'I trow Botrell woll nott dyshease yow off yowre howsse noo lenger' - but in the context of the earlier letters this seems the most obvious translation of his meaning. See also Rose, Calais: An English Town in France, p. 107 and Hanham, Celys and their World, pp. 264-5. 